\title{
American Federalism in the 1990s
}

\author{
David C. Datellet
}

David C. Datelle is studying social policy analysis and evaluation at The George Washington University. He earned a bachelor's degree in political science at Le Moyne College in Syracuse, New York. He is now working as a criminal justice policy analyst at The American Prosecutors Research Institute.

On January 25, 1994, President Clinton gave a State of the Union Address that included a lofty agenda for reforms by the federal government in the areas of welfare, health care, criminal justice and education. ${ }^{1}$ While the majority of his speech stressed the importance of these issues, the President failed to offer any specifics about the funding of these reforms and the level of government that would be responsible for the delivery of these programs.

Each of President Clinton's reform measures involves questions of intergovernmental relations and federalism. How these issues are handled and, ultimately, how they will be resolved depends largely on the present conditions within the American federal system. With this in mind, this article will focus on both the current status and future direction of the American federal system and how these current and future conditions might affect policy formulation and implementation.

\section{Historical Background of the American Federal System}

The American federal structure was created out of the "turmoil and paralysis" that existed during the era of the Articles of Confederation. ${ }^{2}$ During this time, individual states erected trade barriers against each other, the national power of taxation was minimal, and citizens feared potential military and economic exploitation by Europe. These and numerous other problems led to a call for a more cohesive, centralized system of governance, one that would ensure political and economic stability.

Accompanying this call for a new government was a debate about the autonomy the states would retain under this new system of government. This debate culminated in a compromise on the allocation of governmental responsibilities, with the states retaining a substantial degree of autonomy. ${ }^{3}$ Thus, while the evolution of the American federal system has led to a more active and dominant federal government, the states have continued to play a substantial role in the domestic policy arena. In addition, the states are presently assuming more responsibility in areas which were previously the exclusive domain of the federal government.

\section{The Current Status of the American Federal System}

The current intergovernmental landscape is characterized . by constant tension and competition among levels of government. States are now more reluctant to implement federal programs which contain stringent guidelines and limited funding. In his book, Understanding Intengovernmental Relations, Deil S. Wright introduces an "overlapping-authority" model that accurately illustrates this tension and competition between the states and the federal government." According to Wright, there are six characteristics which make up this model. They are:

- limited and dispersed power

- modest and uncertain areas of autonomy

- high degree of potential or actual interdependence

- simultaneous competition and cooperation

- bargaining-exchange relationships

- negotiation as a strategy for reaching agreement ${ }^{5}$

The six variables within this model represent a general picture of how American federalism works although these variables fluctuate from time to time depending on the political and fiscal climate during a given era. For example, during the 1960 s the federal government had easy access to various sources of revenue and the political climate favored a national response to pressing policy concerns. This led to an emphasis on cooperation 
between the federal government and the states on the allocation of governmental responsibilities. Conversely, the 1980s saw a rapid decline in the fiscal advantage of the federal government along with a political environment characterized by decentralization. As a result, the variables of competition, negotiation and bargainingexchange relationships took precedence over cooperation between the states and the federal government.

From 1929 until 1978, there was a substantial degree of cooperation at all levels of government. ${ }^{6}$ After World War II, states were willing to cooperate with the federal government because the federal government provided substantial program funding. However, since 1978 a weakened federal fiscal capacity - caused by large budget deficits - caused the pendulum to swing away from centralization in favor of more competition between the states and the federal government.?

Building on Wright's analysis, John Shannon of The Urban Institute and James Edwin Kee of The George Washington University have chronicled this shift away from centralization and have referred to the present period as one of "Competitive Federalism." ${ }^{8}$ Under competitive federalism, the federal government is free to enter into virtually any area of domestic policy. The Supreme Court's reluctance to overturn acts of Congress, particularly acts pursuant to Congress's interstate commerce powers, has helped to pave the way for potential federal involvement in virtually any domestic area. In addition, the federal government once held a clear fiscal advantage over the states; federal income tax revenues were growing nearly twice as fast as the economy, allowing for the creation and implementation of many new federal programs. Since 1978, however, this federal fiscal advantage has evaporated due to federal income tax rate cuts and rising budget deficits. These, in turn, have created a "fend-for-yourself" fiscal environment where federal and state officials are forced to compete directly for taxpayer support. ${ }^{9}$

Currently, this trend toward increased competition is having a substantial effect on policy formulation and implementation. The states are now demonstrating renewed policy leadership in such diverse areas as health care, education, the environment and economic development. Even in areas where the federal government is still playing a prominent role, states are resisting any restrictive federal guidelines that are not accompanied by federal aid. Withour the federal fiscal inducements, the national government now needs state and local cooperation if effective implementation of any national program is to occur.
The notion of competitive federalism has been challenged by a number of contemporary commentators. In Crisis and Leviatban, Robert Higgs concludes that government centralization was the result of social crises such as World War II and the Great Depression. Once these crises ended, centralization at the federal level remained and, as Higgs predicts, will continue to remain for the near future in contrast to Shannon and Kee's thesis that power will be shared among many competitive governmental actors. ${ }^{10}$ In "Federalism - The Great 'Composition'", Richard P. Nathan challenges Higgs' centralization thesis by arguing that responsibility for domestic policy fluctuates with changing political ideologies." According to Nathan, the Reagan doctrine of decentralization served as a catalyst for increased state responsibility and leadership. Reagan's ideology represented a complete transformation from the Great Society era, when a national response was favored.

\begin{tabular}{c}
\hline \hline "States are now more likely \\
than ever to take the initiative \\
on pressing policy concerns \\
because the federal government \\
no longer bas the fiscal \\
wherewithal or the political \\
momentum to do so"
\end{tabular}

Based on the current fiscal crisis facing the federal government, Shannon and Kee's conclusions are more compelling than the theories of either Higgs or Nathan. Higgs and Nathan both neglect to address the substantial effect that federal fiscal realities are having upon the distribution of . domestic policy responsibilities. Tight federal budgets, federal commitment to deficit reduction, a reluctance to raise federal individual income taxes and a growing concern over federal transfer payments for individuals, also known as entitlements, have all contributed to the reduction of federal aid and federal leadership during the last 16 years..$^{12}$ As a result, states are now more likely than ever to take the initiative on pressing policy concerns because the federal government no longer has the fiscal wherewithal or the political momentum to do so. Indeed, the decade of the 1980s represents the renaissance of the states as domestic program initiators. ${ }^{13}$ States have even begun to enter into or expand their presence in areas that heretofore were considered exclusively federal. 


\section{"Perennial Dilemmas"14}

Many contemporary commentators have noted that the study of federalism tends to be dry, arcane and devoid of any relevance in an urbanized, technologically advanced and economically sophisticated country such as the United States. On the contrary, federalism is important for modern America and makes a substantial difference in the political, social and economic life of every American. ${ }^{15}$

In his book, Federalism: The Politics of Intergovernmental Relations, David C. Nice of the University of Georgia illustrates how the theory of federalism translates into practice. He cites six "perennial dilemmas" that are endemic to the American federal system. With each dilemma, a trade-off exists between two equally unsatisfactory alternatives, neither of which contains a permanent solution. Three of these six dilemmas will be addressed to illustrate the effect they have on the American federal system. They are:

- Flexibility versus Uniformity

- Policy Innovation versus Dispersion

- Liberty versus Unresponsiveness ${ }^{16}$

In the American federal system, a trade-off frequently exists between flexibility at the state and local level and uniformity at the federal level. State and local governments want the flexibility to respond to policy problems in a manner that is consistent with their particular situation. Conversely, the federal government wants to set uniform national standards that will bring into balance state and regional inequalities in services and resources. Any benefit to the states involves a corresponding detriment to the federal government.

According to Nice, the interjurisdictional makeup of the federal system allows for policy innovation and experimentation to occur at the regional level. ${ }^{17}$ New approaches to policy problems may be created and tested at the regional level, which is less expensive than implementing a program nationwide. Thus, when program failure does occur, it does so on a regional scale rather than on a national one. However, a major drawback to this regional approach is that once a successful program is developed, the "multiplicity of decision centers" usually hinders national implementation of new innovations. ${ }^{18}$.

The abduction and subsequent murder of 12 -year-old Polly Klaas of Petaluma, California, in October 1993 offers a tragic example of the real-life implications of Nice's second dilemma of policy innovation versus dispersion." Polly Klaas' abductor, a twice-convicted kidnapper, was stopped by Sonoma County sheriffs deputies approximately 90 minutes after he had taken the child from her home..$^{20}$ By this time, the Petaluma Police Department had sent a description of the kidnapper over the California Law Enforcement Teletype System (CLETS). However, Sonoma County sheriffs deputies were restricted from broadcasting the man's previous criminal convictions over the CLETS because public access to these signals jeopardizes a suspect's right to privacy under Califomia law. ${ }^{21}$

According to Sergeant Mike Neece of the Petaluma Police Department, thousands of law enforcement agencies across the United States have solved this problem by installing a Mobile Display Terminal (MDT) within each police cruiser. The MDT allows an officer to access a suspect's criminal record without violating that suspect's right to privacy. Unfortunately, the Sonoma County Police Department has yet to install MDT's in any of their police cruisers. If the federal government had mandated the installation of the MDT nationwide, Polly Klaas might still be alive today. On the other hand, if the federal government had control over law enforcement issues, issues which are more familiar to local authorities, then development and dispersion of the MDT might never have occurred.

\begin{tabular}{c}
\hline \hline "In the American federal system, \\
a trade-off frequently exists between \\
flexibility at the state and local \\
level and uniformity at the federal \\
level. . . Any benefit to the states \\
involves a corresponding detriment \\
to the federal government." \\
\hline \hline
\end{tabular}

Nice's third dilemma centers around the protection of individual rights versus governmental responsiveness. ${ }^{23}$ By creating a governmental structure in which power was limited and dispersed, the Founders sought to prevent centralization of power by any one group in society. However, the same features that protect against concentrated, monopolistic power have the unwanted effect of creating unresponsiveness at the state level. States are often slow to implement national programs if they feel that these initiatives will conflict with state prerogatives. Conversely, when the federal government tries to remedy regional unresponsiveness, the ability of the states to act as buffers against centralized, monopolistic power is then compromised. ${ }^{24}$ 


\section{Illustrations of the Current Conditions within the American Federal System}

\section{Congressional Anti-Crime Initiatives}

In response to recent headlines and increased public outrage over violent crime, legislation has been introduced in Congress that would make the reduction of violent crime a national priority. Under the Senate's Violent Crime Act ( $S .1607)$, states would be required to follow federal guidelines regarding pre-trial detention, sentencing and parole policies. ${ }^{25}$ The states have strongly opposed these proposed crime measures because they contain a number of unfunded mandates, i.e., federal orders to states not accompanied by federal aid. This bill would authorize $\$ 3$ billion in funding to the states, but the long-term costs that would accrue are predicted to exceed $\$ 12$ billion nationwide. ${ }^{26}$ The House version of the crime bill offers funding for 100,000 new police officers over the next five years. However, the states would be responsible for paying the salaries of these new officers after five years at a cost of $\$ 8.9$ billion nationwide.27

The intention of these provisions is to federalize crime policy without infringing on another federal priority deficit reduction. Fiscal constraints are forcing the federal government to resort to the use of unfunded mandates as a means of achieving uniformity and national standards. However, without adequate funds to accompany these mandates, the role of the federal government in criminal justice policy will depend on state cooperation.

\section{Homelessness}

According to the Hon. Henry G. Cisneros, Secretary of the Department of Housing and Urban Development (HUD), the Department's top priority for fiscal year (FY) 1994 is homelessness. ${ }^{23}$ However, the Clinton administration's FY '94 budget authorizes only $\$ 823$ million to HUD to combat the nationwide homelessness problem. ${ }^{2}$ To put this figure into perspective, New York City's Department of Homeless Services alone currently spends $\$ 500$ million a year on homelessness, only $\$ 323$ million less than the national total for FY " $94 .{ }^{30}$ While the federal government proclaims that homelessness is a national concern, Clinton administration officials are not supporting these statements with federal funds.

The federal government continues to struggle with inadequate funding and conflicts about proper program implementation in this area, which leaves cities all over the United States with the prospect of addressing homelessness according to local standards. For example, the city of Orlando, Florida, built a 30,000-square-foot, $\$ 1.3$ milliona-year Coalition Campus for the homeless through a public-private partnership..1 The Orlando facility is unique among homeless shelters because it accepts anyone from the Orange County area, regardless of physical or mental condition. In addition, the Coalition Campus is one of the only homeless shelters in the country that provides free substance abuse and mental health counseling, adult education and mail services within the same building. ${ }^{32}$ According to Michael Poole, president of the Coalition for the Homeless of Central Florida, the results of this publicprivate initiative have been so positive (petty crime has dropped 40 percent to 50 percent downtown along with cost savings in police time and prison beds) that Dade County officials are planning to build three similar facilities in Miami over the next three years.33

The Orlando illustration is important for two reasons. First, it represents a current example of how policy innovation is being stimulated at the state level. In most situations, such as homelessness, local officials are better equipped than the federal government to design effective and efficient programs in accordance with their personal knowledge of that region. In Orlando, city officials decided to provide multiple services in one location after realizing that provision of shelter was not enough to solve the problem of homelessness. ${ }^{34}$ Second, this illustration represents a concrete example of how states and their subdivisions are taking the lead on policy concems absent federal leadership, mandates and federal aid.

\section{The Future Direction of the American Federal System}

Coercion (i.e., unfunded mandates) and competition will continue to result in debate among levels of government over the proper role of each player within a given policy domain. Whether the federal government or the states will gain the upper hand in this struggle will depend largely upon the fiscal capacity of the federal government and the political ideology of elected federal officials. Of the two (unfunded mandates notwithstanding), the fiscal capacity of the federal government will be the best indicator of how the federal landscape may look over the next 15 to 20 years. According to the Congressional Budget Office, the federal deficit is projected to increase substantially after $1997 .{ }^{35}$ If these projections hold true, the states will be forced to take on more responsibility in the domestic policy arena. 
Regardless of federal leadership and funding, problems pertaining to the environment, education, homelessness and economic development still remain. Under these circumstances, the states have no other altemative but addressing these pressing problems from a pragmatic standpoint. Despite renewed policy activity at the state level, many officials within the federal government fear that urgent policy problems will be either inadequately addressed or completely unaddressed; these officials also fear that state solutions to problems will be driven by parochial interests instead of nationwide standards. Nonetheless, over the last five years the states and their subdivisions have addressed such pressing national concerns as education and economic development with surprising success. Also, officials at the state and local levels proved on numerous occasions that they are better equipped to deal with many of these policy problems in a practical and efficient manner. The Polly Klaas case and the Orlando example have already illustrated this point.

According to Alice M. Rivlin, Deputy Director of the federal Office of Management and Budget, the "multiple centers of power" and "interjurisdictional relationships" that characterize the American federal system are causing government ineffectiveness at all levels. ${ }^{36}$ Rivlin suggests a legislative solution to this problem, which would include a clear "distinction between federal responsibilities and those of state and local government. ${ }^{37}$ Unfortunately, this division of responsibility, or sorting out of functions, may alter the present federal structure in ways that are unintended and unwanted. Nice argues that solutions to government ineffectiveness which call for a separation of functions or a redistribution of responsibility among levels of government represent "proposals which will aiter the scope of conflict." ${ }^{m 8}$ For example, if one level of government has complete control over health care, citizens will not be able to turn to another level of government if program failure occurs. "Shared responsibilities" and tension within the American federal system ensure that individual rights will be protected and failure by one level will be followed by corrective action by other levels. ${ }^{39}$

"The solutions to the problems
facing the American federal system
do not lie with an end to the
tug-of-war between the states
and the federal government. On the
contrary, the solutions might...
be realized through the
continuation of this struggle."

The solutions to the problems facing the American federal system do not lie with an end to the tug-of-war between the states and the federal government. On the contrary, the solutions might actually be realized through the continuation of this struggle. One of the reasons the Founders built this tension into the federal system was to insure that power would oscillate between a strong, centralized federal government and a semi-autonomous, decentralized federal structure. As James Madison noted in Federalist No. 39, the new American system is "neither wholly national or wholly federal" but "a composition of both." ${ }^{\prime \prime 0}$ The Founders never intended to set boundaries, create specific limits, or sort out appropriate roles for each level of government. To have done so would have been an admission that predetermined roles are necessary based on a set of immutable circumstances or conditions, an admission that the Founders might not have been willing to make. $\star$

\section{Notes}

I I am -indebted to Debbie Kuntz, my editor, whose encouragement, patience, and editorial comments have made the publication of this article a reality. I would also like to thank Professor James Edwin Kee, Tom Fulham, and Larry Boyer for their assistance and editorial comments.

1 President Clinton, "State of the Union," Wasbington Post, 26 Jan. 1994, p. A12.

2 Craig R. Ducat and Harold W. Chase, Constitutional Interpretation, 4th ed. (New York: West Publishing Company, 1988) p. 355.
3 Ibid., p. 355.

4 Deil S. Wright, Understanding Intergovernmental Relations, 3rd ed. (Pacific Grove: Brooks/Cole Publishing Co., 1988) p. 58.

5 Ibid., p. 57.

6 John Shannon and James Edwin Kee, "The Rise of Competitive Federalism," Public Budgeting and Finance (Winter 1989): p. 6.

7 Ibid., p. 6 
${ }^{8} \mathrm{John}$ Shannon and James Edwin Kee note that the term "Competitive Federalism" has been used before by other commentators. However, its general use has been limited to a discussion of horizontal competition for investment and jobs - interstate and intercity - not competition among layers of governments. A few recent works on competitive federalism in the narrower context include Daphne Kenyon and John Kincaid, "Rethinking Interjurisdictional Competition," Multistate Tax Commission (Oct. 1988): pp.12-14; Daphne A. Kenyon, "Interjurisdictional Tax and Policy Competition; Good or Bad for the Federal System?" (Washington D.C.: ACR paper, 7 Jan. 1988, reprinted by the Urban Institute, February 1988); U.S. Advisory Commission on Intergovernmental Relations, Interjurisdictional Competition in the Federal System: A Roundtable Discussion, M-157 (Washington, D.C.: ACIR, Aug. 1988).

9 John Shannon first coined the term "fend-for-yourself federalism" in "The Return to Fend-for-Yourself Federalism," Intergovernmental Perspectives 13 (Summer/Fall, 1987).

${ }^{10}$ Shannon and Kee, p. 19.

\section{Ibid.}

12 Ibid., p. 12.

13 Ibid., p. 6.

14 David C. Nice, Federalism: The Politics of Intergovernmental Relations (New York: St. Martin's Press, 1987) p. 207.

15 Christopher Hamilton and Donald T. Wells, Federalism, Power, and Political Economy: A New Theory of Federalism's Impact on American Life, (Englewood Cliffs, New Jersey: Prentice Hall, 1990) xiii.

16 Nice, pp. 208-209.

17 Ibid., p. 208.

18 Ibid.

19 Michael Neece, Sergeant, Petaluma Police Department, telephone interview, 8 March 1994.

20 Ibid.

21 Ibid.
22 Ibid.

23 Nice, p. 209.

24 Ibid.

25 Denton Darrington, letter to President Clinton, 19 November 1993, 1.

26 Ibid.

27 Sari Siegel, "Tough on Crime: The Fed's Forked Tongue in State Government News (Washington, D.C.: 1994, forthcoming), p. 1.

28 Office of Special Needs and Assistance Programs, Department of Housing and Urban Development, telephone interview, 8 March 1994.

29 Office of Special Needs and Assistance Programs, HUD.

30 Ted Houghton, Chief of Staff, New York City Department of Homeless Services, telephone interview, 8 March 1994.

31 Michael Poole, President, The Coalition for the Homeless of Central Florida, telephone interview, 8 March 1994.

32 Ibid.

33 Ibid.

34 Ibid.

35 Alice M. Rivlin, Reviving the American Dream: The Economy, the States and the Federal Government, (Washington, D.C.: The Brookings Institution, 1992), p. 111.

36 Jbid., p. 3

37 Ibid.

38 Nice, p. 216.

39 Ibid., p. 217.

40 Richard P. Nathan, "Federalism -The Great 'Composition'", in The New American Political System, (Washington, D.C.: 1990), p. 1.

\section{Bibliography}

Bowman, Ann O' M., and Richard C. Kearney, The Resurgence of the States, Englewood Cliffs, N.J.: Prentice-Hall, 1986.

Clinton, William, "State of the Union Address," Wasbington Post, 26 Jan. 1994, A12.

Darrington, Denton, Letter to President Clinton, 19 Nov. 1993, 1-2.
Ducat, Craig R., and Harold W. Chase, Constitutional Interpretation, 4th ed., St. Paul, Minn.: West Publishing Company, 1988.

Elazar, Daniel, American Federalism, 3rd ed, New York: Harper and Row, 1984.

Felde, John, and Donna Hunzeker, "Making It a Federal Case," State Legislatures, Sept., 1993. 
Garcia v. San Antonio Metropolitan Transit Autbority, 469 U.S. 528 (1985).

Glendening, Parris, and Mavis Reeves, Pragmatic Federalism, 2nd ẹd., Pacific Palisades, Calif.: Palisades, 1984.

Grodzins, Motton, The American System, New Brunswick, N.J.: Transaction,1984.

Hamilton, Christopher, and Donald T. Wells, Federalism, Power, and Political Economy: A New Theory of Federalism's Impact on American Life, Englewood Cliffs, N J: Prentice-Hail, Inc., 1990.

Higgs, Robert, Crisis and Leviathan, New York: Oxford University Press, 1987.

Houghton, Ted, telephone interview, 8 March 1994.

Kenyon, Daphne A., and John Kincaid, Competition Among States and Local Governments: Efficiency and Equity in American Federalism, Washington, D.C.: The Urban Institute Press, 1991.

- "Rethinking Interjurisdictional Competition," Multistate Tax Commission, Oct. 1988: 12-14.

Matheson, Scott $M$., and James Edwin Kee, Out of Balance, Layton, Utah: Gibbs M. Smith, Inc., 1986.

Musgrave, Richard and Peggy Musgrave, Public Finance in Theory and Practice, 3rd ed., New York: McGraw-Hill, 1980.

Nathan, Richard P., "Federalism - The Great "Composition." The New American Political System, Anthony King, ed., 2nd ed., Washington, D.C.: 1990.

Neece, Michael, telephone interview, 8 Mar. 1994.

New York v. United States, 112 S.Ct. 2408 (1992).

Nice, David C., Federalism: The Politics of Intergovernmental Relations, New York: St. Martin's Press, 1987.
O'Toole, Laurence J., Jr., American Intergovernmental Relations, Washington, D.C.: Congressional Quarterly Inc., 1993.

Poole, Michael, telephone interview, 8 March 1994.

Rivlin, Alice M., Reviving the American Dream: The Economy, the States $\&$ the Federal Government, Washington, D.C.: The Brookings Institution, 1992.

Robertson, David B., and Dennis R. Judd, The Development of American Public Policy: The Structure of Policy Restraint, Glenview, IIl.: Scott, Foresman and Co., 1989.

Shannon, John, and James Edwin Kee, "The Rise of Competitive Federalism," Public Budgeting \& Finance, Winter (1989).

Shannon, John, "The Return to Fend-for-Yourself Federalism," Intergovernmental Perspectives 13 (Summer/Fall, 1987).

Siegel, Sari, "Tough on Crime: The Fed's Forked Tongue," State Government News (forthcoming).

United States, Advisory Commission on Intergovernmental Relations, Changing Public Attitudes on Government and Taxes. Washington, D.C.: 1982.

United States, Department of Housing and Urban Development, Office of Special Needs and Assistance Programs, telephone interview, 8 March 1994.

Wright, Deil S., Understanding Intergovernmental Relations, 3rd ed., Pacific Grove, Calif: Brooks/Cole Publishing Co., 1988.

Zimmerman, Joseph F., Contemporary American Federalism: The Growth of National Power, Greenwood Publishing Group, Inc., 1992. * 